lung fibrosis due to Thorotrast despite the many thousands of patients injected with it. ${ }^{239}$ The type of injection (thoracic fistulography), however, appears to have been rare. Among 168 patients described by Boyd et al $l^{\beta}$ who received Thorotrast, 141 had intra-arterial injections and 27 cerebral ventricular or subarachnoid injections.

Particles were found in the liver and spleen of our patient and microscopy of the lung tissue suggested transendothelial passage. Probably thorium particles were resorbed by lymphatics from the tissue around the fistulas and passed into the bloodstream. The presence of thorium particles in the blood vessel walls suggests that this "embolisation" process was continuing at the time of lung biopsy, which is consistent with the episodes of pulmonary oedema that characterised our patient's illness. It is also possible that thoracic lymphatic drainage was impaired by adhesions between the parietal and visceral pleura, and by obstruction due to thorium induced fibrosis ${ }^{13}$ in thoracic lymph nodes, thus reducing the clearance of lung particles and increasing their retention in the interstitium of the lung.

We conclude that lung fibrosis should be considered as a late complication of thoracic fistulography with Thorotrast.
We thank Mr J Bette for his help in calculating the radiation dosage; Professor C A Wagenvoort for reviewing the tissue sections; Professor D V Bates, who referred the patient; and Dr M Jane Thomas for the necropsy report.

1 Abbatt JD. History of the use and toxicity of Thorotrast. Environ Res 1979;18:6-12.

2 Janower ML, Miettinen OS, Flynn MJ. Effects of long-term Thorotrast eposure. Radiology 1972;103:13-20.

3 Boyd JT, Langlands AO, Maccabe JJ. Long-term hazards of Thorotrast. Br Med J 1968;ii:517-21.

4 Mori T, Maruyama T, Kato Y, Takahashi S. Epidemiological follow-up study of Japanese Thorotrast cases. Environ Res 1979;18:44-54.

5 Looney WB. An investigation of the late clinical findings following Thorotrast (thorium dioxide) administration. AJR 1960;83:163-85.

6 Abrahamson L, O'Connor M, Abrahamson M. Bilateral alveolar lung carcinoma associated with injection of Thorotrast. Ir J Med Sci 1950;6:229-35.

7 International Commission on Radiological Protection. Individual monitoring for intakes of radionuclides by workers. Report of a task group. Oxford: Pergamon Press, 1988:201-7. (ICRP publication 54.)

8 Dahlgren S. Effects of locally deposited colloidal thorium dioxide. Ann N Y Acad Sci 1967;145:786-91.

9 da Silva Horta J. Late effects of Thorotrast on the liver and spleen, and their efferent lymph nodes. Ann N Y Acad Sci 1967;145:676-99.

10 Fraser RG, Paré JAP. Diagnosis of diseases of the chest. Vol 2 2nd ed. Philadelphia: Saunders, 1978:1217-27.

11 Grillmaier R, Muth H. Radiation dose distribution in lungs of Thorotrast patients. Health Phys 1971;20:409-19.

12 Kaul A, Foll U, Haase V, Palme G, Riedel W, Stoepmann HJ. Microdistribution of Thorotrast and dose to cellular structures. Environ Res 1979;18:13-22.

13 Bensinger TA, Keller AR, Merrell LF, O'Leary DS. Thorotrast-induced retriculoendothelial blockade in man. Am J Med 1971;51:663-8.

\section{Adult respiratory distress syndrome after limited resection of adenocarcinoma of the lung}

\author{
Sherif El Bayadi, David B Ettensohn, \\ John Yashar
}

\footnotetext{
Brown University Program in Medicine, Roger Williams General Hospital, Memorial Hospital of Rhode Island, Providence, Rhode Island, USA $S$ El Bayadi D B Ettensohn Department of Surgery $\mathrm{J}$ Yashar

Address for reprint requests: Dr David B Ettensohn, Division of Pulmonary Medicine, Memorial Hospital of Rhode Island, Pawtucket, Rhode Island 02860, USA.

Accepted 20 June 1990
}

\begin{abstract}
Two cases of the adult respiratory distress syndrome developed after limited resection for lung carcinoma. No other known precipitants were evident. The adult respiratory distress syndrome is a clinical expression of acute lung injury ${ }^{1}$ that may arise from various insults and include air and blood borne factors. ${ }^{2}$ Tumour related blood borne factors may have contributed to lung injury in these cases.
\end{abstract}

\section{Case reports}

CASE 1

A 71 year old woman with a history of obstructive airways disease underwent resec- tion of a mass in the right lung. Preoperative pulmonary function tests showed a one second forced expiratory volume $\left(\mathrm{FEV}_{1}\right)$ of 0.96 litres $(60 \%$ predicted) and a forced vital capacity (FVC) of 1.621 (70\% predicted). When she was breathing air her $\mathrm{pH}$ was $7 \cdot 40$, arterial carbon dioxide tension $\left(\mathrm{PaCO}_{2}\right) 4.0 \mathrm{kPa}$, and arterial oxygen tension $\left(\mathrm{PaO}_{2}\right) 8.5 \mathrm{kPa}$. No evidence of mediastinal disease was seen on a chest computed tomogram or at mediastinoscopy. Right upper and middle lobectomies were performed. She was extubated without difficulty two days later. On the third postoperative day she developed mild dyspnoea. This rapidly progressed in severity and diffuse bilateral alveolar infiltrates were noted on her chest radiograph.

Her temperature was $38^{\circ} \mathrm{C}$ and white blood cell count $12.2 \times 10^{9} / 1(90 \%$ segmented forms, $4 \%$ lymphocytes, $3 \%$ band forms, and $3 \%$ monocytes). Arterial blood gas analysis while she breathed oxygen (fractional inspired oxygen $\left(\mathrm{FIO}_{2}\right) 60 \%$ ) showed: $\mathrm{pH} 7 \cdot 40, \mathrm{PaCO}_{2}$ $5.3 \mathrm{kPa}$, and $\mathrm{PaO}_{2} 4.9 \mathrm{kPa}$. She was intubated; urine, blood, and sputum were cultured; and empirical treatment with gentamicin and mezlocillin was started. Pulmonary capillary wedge pressure was $8 \mathrm{~mm} \mathrm{Hg}$ and cardiac output was $5.90 \mathrm{l} / \mathrm{min}$. Bronchoscopy showed scanty mucus in the left lower lobe bronchus and an intact anastomotic site. She did not respond to treatment and died on the seventh postoperative day. At necropsy the lung showed changes consistent with the adult respiratory distress syndrome with no 
evidence of tumour or of systemic or local infection. All cultures were negative.

CASE 2

A 50 year old woman with systemic sclerosis underwent sleeve lobectomy of the right upper lobe for a well differentiated adenocarcinoma. Her preoperative assessment showed no metastatic disease; her $\mathrm{FEV}_{1}$ was $90 \%$ and FVC $86 \%$ predicted. She was a heavy smoker (two packs a day for over 20 years), and had a history of alcohol misuse in the distant past. On the second postoperative day, after extubation, arterial blood gas analysis showed: $\mathrm{pH} 7 \cdot 36, \mathrm{PaCO}_{2} 5 \cdot 1 \mathrm{kPa}$, and $\mathrm{PaO}_{2} 11.6 \mathrm{kPa}$ while she was breathing oxygen $\left(\mathrm{FIO}_{2} \mathrm{0} \cdot 3\right)$. The next day she developed rapidly progressive respiratory failure requiring reintubation. Pulmonary capillary wedge pressure was $10 \mathrm{~mm} \mathrm{Hg}$ and cardiac output $5.97 \mathrm{l} / \mathrm{min}$. A chest radiograph showed diffuse alveolar infiltrates and right lower lobe collapse. A small amount of mucus was cleared at bronchoscopy. No cultures, including those for Legionella pneumophila and mycobacteria, showed any growth. Empirical treatment was started with gentamicin and mezlocillin, and later erythromycin was added. A positive end expiratory pressure of 5 $\mathrm{cm}$ and an $\mathrm{FIO}_{2}$ of 0.5 were needed to maintain a $\mathrm{PaO}_{2}$ of $8.7 \mathrm{kPa}$. She recovered after a long stay in the intensive care unit.

\section{Discussion}

The development of the adult respiratory distress syndrome in various clinical settings has led to the idea that it represents a final common expression of diffuse lung injury. ${ }^{1}$ For most precipitants injury can be attributed to exposure to inhaled or blood borne factors. ${ }^{2}$ Our cases differ in that the adult respiratory distress syndrome developed in the absence of detectable systemic illness. Both cases followed routine thoracotomy for tumour resection and were uncomplicated by infection, haemodynamic disturbances, or toxic exposure.

The adult respiratory distress syndrome has been reported after systemic chemotherapy ${ }^{3}$ and limited thoracic radiotherapy for pulmonary malignancy, ${ }^{4}$ and in association with lymphangitic spread of malignancy. ${ }^{56}$ Faber $e t$ al reviewed 101 patients who underwent sleeve lobectomy and reported one case of the adult respiratory distress syndrome, ${ }^{7}$ but did not detail the surrounding events. Neither patient reported here had received chemotherapy or radiotherapy and no malignant lymphangitic spread was found at operation in either case or at necropsy in the first case. We cannot completely exclude an untoward "drug" reaction to an anaesthetic agent or to an antibiotic or other routine medication; but the absence of other clinical indicators argues against the latter type of reaction and anaesthetic agents as a cause of the adult respiratory distress syndrome have not been reported before.

There may be an aetiological association between the adult respiratory distress syndrome and mediators such as cachectin (tumour necrosis factor), interleukins, leukotriene B4, interferons, and prostaglandins. ${ }^{2}$ These factors are released by macrophages or lymphocytes, or both, frequently as a result of their interaction; and both cell types play a part in the host response to malignancy. ${ }^{8}$ Tumour necrosis factor is a mediator of tissue injury ${ }^{9}$ and could be produced by the cell mediated immune response to malignancy. ${ }^{10}$ Release of tumour necrosis factor (and other tumour induced immune response mediators) by tumour manipulation at surgery may have played a part in the development of the adult respiratory distress syndrome in our patients. We hope that these cases will alert others to the possibility of the adult respiratory distress syndrome after thoracotomy for tumour resection and encourage further investigation of its pathogenesis.

1 Murray JF, Matthay MA, Luce JM, Flick MR. An expanded definition of the Adult Respiratory Distress Syndrome. Am Rev Respir Dis 1988;138:720-3.

2 Flick MR. Mechanisms of acute lung injury: what have we learned from experimental animal models? Crit Care Clinics 1986;2:455-70.

3 Rao SX, Ramaswamy G, Levin M, McCravey JW. Fatal acute respiratory failure after Vinblastine. Mitomycin therapy in lung carcinoma. Arch Intern Med 1985;145 1905-7.

4 Fulkerson WJ, McLendon RE, Prosnitz LR. Adult respiratory distress syndrome after limited thoracic radiotherapy. Cancer 1986;57:1941-6.

5 Gore TB, Innes DJ, Romney R, Stone DD, Hess CE. Adul respiratory distress syndrome due to malignant histiocytosis. Southern Med J 1985;78:858-62.

6 Morris-Portmann T, Zimmerman A, Hasler S, Muller U Adult respiratory distress syndrome with intraalveola metastatic amelanotic melanomas. Schweiz Med Wochens chr 1984;114:25-9.

7 Faber LP, Jensik RJ, Kittle CF. Results of sleeve lobectomy for bronchogenic carcinoma in 101 patients. Ann Thorac Surg 1986;37:279-85.

8 DeVita VT, Hellman S, Rosenberg SA, eds. Principles and practice of oncology. Philadelphia: Lippincott, 1989 $301-47$.

9 Tracey KJ, Beutler B, Lowry SF, et al. Shock and tissue injury induced by recombinant human cachectin. Science 1986;234:470-4.

10 Beutler B, Cerami A. Cachectin: more than a tumor necrosis factor. N Engl J Med 1987;316:379-85. 